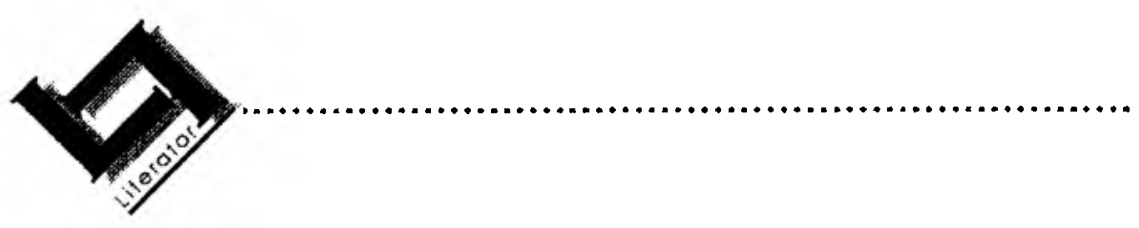

\title{
Verset en volharding: die lewe van Rachel Isabella (Tibbie) Steyn gedurende die Anglo- Boereoorlog
}

The dead live again every time we

remember them (Maeterlinck)

\author{
Elbie Truter \\ Eenheid vir Taalfasilitering en Taalbemagtiging \\ Universiteit van die Vrystaat \\ BLOEMFONTEIN \\ E-pos: trutere@opv.uovs.ac.za
}

\begin{abstract}
Resistance and perseverance: The life of Rachel Isabella (Tibbie) Steyn during the Anglo-Boer War
\end{abstract}

Rachel Isabella (Tibbie) Fraser was born in 1865 in Philippolis as daughter of the Rev. Colin McKenzie Fraser (Jr) and Isabella Paterson of Scotland, and granddaughter of a Scottish immigrant, the Rev. C.A. Fraser. Tibbie was trained as a teacher in Bloemfontein at the "Dames-instituut" (Eunice) after which she married advocate Marthinus Theunis Steyn, a prominent Free Stater. When Theunis was elected State President of the Orange Free State in 1896, Tibbie distinguished herself as hostess of the Presidency.

Tibbie experienced the vicissitudes of the Anglo-Boer War, fleeing before the victorious British army from one northeastern Free State town to the other. She was captured at the end of July 1900 and was regarded at the "first woman in her position to be taken prisoner". Tibbie was interned in Bloemfontein and became an example of the adamant resistance of the Afrikaner woman against British domination. She was elected as "one of the worst of a number of irreconcilable women" to be deported from South Africa. The order was, however, rescinded at the last moment, after Kitchener had failed to produce conclusive evidence of any misdemeanours. She tended to her husband during his serious illness in Europe and once back in South Africa, achieved honour in uplifting Afrikaners after the war. 


\section{Inleiding}

"There is such joy", het Tibbie se Joodse vriendin, Elsa Leviseur in 1902 geskryf, "and such sorrow in remembering that one might hesitate to tear away the veil from the past. And yet, need there be a tearing rendering?" (Leviseur, 1902:Diary October 1899 - March 1900) Inderdaad. Die pyn waarmee die losruk van herinneringe en geheimenisse uit die verlede gepaard gaan - volgens dié gedagte - impliseer nie noodwendig net droefheid en verwyt nie, dit omvat ook vreugde, grootsheid en patos. En daarom hoef die huiwering in onthou nie getemper te word nie: onthou met deernis, onthou net ... want by die hervertelling van die storie, leef die betrokke rolspelers weer.

Die Anglo-Boereoolog was by uitstek 'n "mens-oorlog" waarin "the human interest", soos generaal J.C. Smuts dit gestel het, "far surpassed its military value" (Reitz, 1929:ix). Die smeltkroes van menslike lyding en eer het die moontlikheid gebied dat die alledaagse en gemiddelde in die mens verhef kon word tot gelouterde glorie of gevalle ontnugtering. Want helde en skurke bestaan immers net in sprokies: in die werklike lewe is daar iets van 'n held in elke skurk en iets van 'n skurk in elke held (Scholtz, 1996:6). Die posisie wat in die stryd verwerf is, het lewenslank jou metgesel geword; het jou in- en uitgange in die Suid-Afrikaanse samelewing bepaal en het jou naam in die annale op watter wyse ook al verewig.

Dit was inderdaad ook die geval met Tibbie Steyn, want sonder die AngloBoereoolog sou haar lewe waarskynlik bloot 'n voetnoot in die annale gebly het. In plaas daarvan is sy begrawe by die Vrouemonument in Bloemfontein - die heiligdom van die Afrikaner - die enigste Suid-Afrikaanse vrou wat dié eer te beurt geval het. Want die oorlog, soos alle oorloê, het tot op die been gesny: in die woorde van Ben Bouwer "it rubbed out every distinction but that of intrinsic value" (Pretorius, 1991:281). Maar sy, en ander gewone mense soos sy, het by uitnemendheid bewys dat "the human soul ... endures", soos Smuts dit gestel het (Reitz, 1929:ix).

\section{2. "A happy free-from-care-existence"}

Tipies was Tibbie nie: sy was 'n Engelssprekende dorpeling met meer Skotse as Afrikanerbloed in haar are. In 'n kultuurarm samelewing waarin die Boer "at least a hundred years behind European thoughts and ideas" was (Haasbroek, 1977:165), was haar milieu hoogs gekultiveerd (Poultney, 1936:55). Sy was verder 'n uitsondering op die Victoriaanse reël wat destyds weinig meer van 'n jong dame verwag het as om "a busy life of household chores" te voer met "decorative activities, sociability and charitable duties, lacking specific direction or purpose" (Bradlow, 1988:20). Dat soveel moeite en koste aangegaan is ten behoewe van enige dogter se opvoeding was uitsonderlik, want die patriargale Boer het eerder die volgende opvatting gehuldig: 
[E]k ... het ... ongeleerd en fatsoenlik deur die wêreld tot sover gekom en kan nog altoos leef; waarom moet ek al die koste vir my kinders maak en nog sonder hul dienste sit? Solank hulle in staat is om die Bybel te lees, 'n baal wol se waarde kan uitreken ... is dit voldoende (Malan, 1929:399)

Rachel Isabella Fraser - Tibbie soos sy volgens Skotse gewoonte informeel genoem is - is in 1865 in Philippolis gebore as die dogter van ds. Colin McKenzie Fraser en 'n Skotse nooi, Isabella Paterson. Haar oupa was een van die Skotse predikante wat lord Charles Somerset na die Kaap gebring het, naamlik ds. Colin Alexander Fraser. Na haar skoling aan die Dames-instituut (Eunice) in Bloemfontein waar sy haar as onderwyseres bekwaam het, en haar huwelik in 1887 met advokaat M.T. Steyn, kon sy haar besig hou met alles behalwe niksseggende ydelhede. Sy het naamlik 'n groot gesin gehad om te beheer, vier dogters en een seun, en 'n Victoriaanse huishouding waarin haar eggenoot meer op reis was vir die Rondgaande Hof as wat hy tuis was (Truter, 1989:84). Klaarblyklik het sy in daardie stadium nog vir sover sy onder Theunis se sterk persoonlikheid gestaan het, nie oor 'n sterk gedefmieerde persoonlikheid beskik nie. Haar senuagtigheid - die "palpitations" wat Theunis so kon irriteer - sou mettertyd, soos sy onder Theunis se sterk invloed uitgekom het, in selfvertroue verander (Ineg: PV 181 2/8/1/1/1. MTS(Boshof)-RIS, 12-10-1888).

As jeugdige presidentsvrou van 'n Boererepubliek sedert Maart 1896, was sy betreklik gevrywaar van teenspoed en wrywing, want nie net was Theunis die onbetwiste pater familias in hul verhouding wat haar as 't ware die hooforganiseerder van die huishouding gemaak het nie, maar haar posisie in die Boere patriargale struktuur het weinig meer van haar vereis was om gesien te word - en dit binne perke - eerder as om gehoor te word. Dit het haar in daardie stadium goed gepas. Wanneer dit van haar verwag was om die woord te doen by 'n geleentheid, soos byvoorbeeld na die presidensiële inswering, het Theunis dit namens haar gedoen (Ineg: PV 181 2/7/1/1/6. RIS(Rustendal)-EH, 8-10-25; De Express, 6-3-1896). Haar onthale in die Presidensie is gekenmerk deur smaak en eenvoud. Besoekers aan die presidentswoning, waaronder die Amerikaner Poultney Bigelow, was verder ook verbaas om in 'n Boererepubliek by so 'n tennis- en teeparty uitsluitlik Engels te hoor sodat hy opgemerk het: "the garden party for all that I could note, ... might have been in England"' (Bigelow, 1898: $100,101)$ Afgesien van enkele verwysings na swak gesondheid na die geboorte van haar jongste dogter, Emeline (Emmie) in 1898 (VKA: Doopregister NGK Bloemfontein (1890-1911); De Express, 18-2-1898; The Friend, 18-2-1898; Cape Argus Weekly, 17-2-1898, 28-9-1898; TAB: SSA 728 RA 1274/98; $4618 / 98$ ), het sy in die woorde van haar vriendin, Dora Poultney, 'n betreklik

1 Dit was in hierdie geval egter geen aanduiding van Engelsgesindheid nie - Engels was tewens haar moedertaal en dic voertaal van die gekultiveerde Afrikaner-dorpeling van destyds. 
"happy free-from-care-existence" gevoer (Ineg: PV 181 2/8/1/1/3 vol. 11. DoraRIS, 16-7-1902) - 'n stand van sake wat selde indien ooit bevorderlik is vir karaktervorming en -verdieping.

Die uitbreek van die Anglo-Boereoorlog in Oktober 1899 vind haar op 34-jarige ouderdom in 'n onbenydenswaardige posisie: sowel sy as Theunis het geen illusies gehad dat die Republieke die oorlog teen Brittanje kon wen nie. Sy het daarby nog nooit nodig gehad om op haar eie voete te staan nie en was vir haar emosionele, geestelike en finansiële behoeftes oormatig aangewese op Theunis, terwyl haar kinders nog betreklik klein was en haar gesondheid soms veel te wense oorgelaat het. Die son het egter nou ondergegaan op hierdie bestaan wat in baie opsigte bevoorreg was.

\section{3. "I was the first woman in my position to be taken prisoner"}

Die instelling van 'n aandklokreël, die sensuur van posstukke en die afwesigheid van gemobiliseerde burgers het in daardie vroeë stadium na die uitbreek van die oorlog skaars 'n rimpeling in die gewone gang van Vrystaatsake veroorsaak. Die euforie geskep deur die aanvanklike skouspelagtige suksesse van die Boererepublieke, het Bloemfontein nog nie verdeel in die latere pro-Britse en proBoere-faksies nie. Gevolglik kon die presidentsvrou nog reken op mildelike bydraes na haar persberoep op klaarverpakte eetware vir versending na die strydende kommando's (De Express, 5-12-1899, 8-12-1899, 30-1-1900). In hierdie vroeë maande van die oorlog was Bloemfontein die deurgangsroete van groot groepe Britse krygsgevangenes onderweg na interneringskampe in die Transvaal. Die lojale Republikeine, waaronder die reeds gemelde Elsa Leviseur, het mekaar omtrent verdring by die spoorwegstasie in hul entoesiasme om Vrystaatse lintstrikkies vir die burgers aan te steek: "[this] splendid set of men It was glorious! Soul stirring!" het hierdie vriendin van Tibbie ekstaties in haar dagboek aangeteken. "Never before have been so mad with excitement ... so utterly oblivous ... so hoarse with shouting and singing Volkslied" (Leviseur Diary, Dagboekinskrywing 23 Oktober 1899; kyk ook Schoeman, 1985:67).

Die toestroming van die eerste gewondes na die Volkshospitaal in Bloemfontein, en daarmee saam die algemeen verswakkende oorlogsituasie, het egter die aanvanklike ekstase getemper: die glorie was net skyn, die emosionele ontlading net onkundige, jeugdige voortvarendheid. Die realiteit van die oorlog het geykte lojaliteite in die Vrystaat vir goed vertroebel en 'n "diversity of attitudes towards political questions within one family" na die oppervlakte gedwing waarvan selfs buitestanders bewus geword het (byvoorbeeld 'n lid van die Russiese ambulans op besoek aan die Presidensie in Bloemfontein; Izedinova, 1977:69). Alhoewel dit 'n tipiese Vrystaatse verskynsel was waar die lojaliteite in elk geval nie volgens Engels-Afrikaanse verdeling verloop het nie, is Tibbie in besonder sleg daardeur getref. Haar ouer broer, Harry, was byvoorbeeld "a full blown Corporal in the Rand Rifles" waar hy die lewenswyse 
en aspirasies van die "Hohenheim"-magskliek van sir Percy Fitzpatrick en sy mede-jingo's gedeel het (VAB: A156 1/1/30. Gordon (Krygsgevangenekamp)RIS, c. Augustus 1901). Gordon, haar jonger broer, weer het opgetree as Theunis se privaatsekretaris tot met sy gevangeneming op Reitz en het hom dus doelbewus lynreg gestel teenoor diegene wat die ondergang van die twee Republieke voorgestaan het.

Na die oorgawe van generaal Piet Cronje by Paardeberg, moes Bloemfontein op 10 Maart 1900 deur die Boeremagte en die presidentspaar voor die seëvierende Britse leërmag ontruim word. Skaars drie dae nadat Tibbie haar laaste verjaarsdag as presidentsvrou op 5 Maart 1900 in die Presidensie gevier het, moes sy in aller yl hul besittings pak. Die houers is by die huis van haar oom, John Fraser, verby gedra om geberg te word by dié van hul goeie vriende, dr. Stollreither - die Duitse konsul - net verder af in St. Georgestraat (Ineg: PV 181 4/8/1/1/3. RIS-MTS, 24-5-1902). Die verhouding tussen haar oom en haar eggenoot, reeds vertroebel drie jaar vantevore tydens die presidensiële verkiesingstryd toe sowel Theunis as John Fraser kandidate was, het nou in die krisisuur verswak tot onversoenbare antipatie. Dit was vir Tibbie 'n pynlike oomblik om op haar dertiende huweliksherdenking die Presidensie fmaal te verlaat, sonder dat sy vir Theunis kon groet of tyd gegun is om haar oudste dogter, Hannah, wat by haar grootouers in Philippolis gekuier het, te gaan haal. Sy is daarna per trein na Kroonstad, die volgende Republikeinse hoofstad (Ineg: PV 181 4/1/2/2 "Gevangeneming").

Nadat Theunis twee dae later die Presidensie verlaat het, is die Union Jack binne twaalf uur daaroor gehys (De Zuid-Afrikaan, 17-3-1900). Alea iacta est: die teerling wat gewerp is, het soos 'n siddering deur die republieke getrek, en die skeidslyne binne die Vrystaatse samelewing is finaal getrek. Tibbie se vriendin, Ella, die Republikeinsgesinde dogter van hul vriende, die Fichardts, het by hul tuinhekkie in Bo-Kerkstraat gestaan: "[1] ... wept until I thought my heart would break" (Schoeman, 1985:21). Hierteenoor het Florence Fraser, John Fraser se dogter en Tibbie se niggie wat saam met haar op skool was, in haar ekstatiese vreugde om die veroweraar te verwelkom, aan die stiebeuel van 'n berede Britse offisier vasgeklou (Schoeman, 1980:159).

Vir die volgende drie maande het Tibbie en haar kinders swerwers geword, aanvanklik agter die rondtrekkende Vrystaatse regering aan en later al vlugtende van een Noordoos-Vrystaatse dorpie na die ander voor die Britte uit. Sy was vir die eerste keer op haarself aangewese terwyl sy fisies dikwels ongesteld was. Die finale verbreking van die naelstring met haar ouerhuis het haar egter geestelik weerbaarder gemaak terwyl haar persoonlikheid ontluik het namate haar emosionele oorafhanklikheid van Theunis verminder het. Finansieel moes sy nou vir die eerste keer kardinale besluite neem en het sy aanvanklik met goue ponde ("sovereigns") in haar besit gereis ten spyte daarvan dat sy dit 'n 
beslommernis gevind het (VAB: CO 74 4309/01 PJ Blignault-sekr luit-goew, 31-12-1901). Op aanbeveling van P.J. Blignault, haar swaer en die gewese Vrystaatse goewermentsekretaris, het sy Theunis se salaris teen sy sin en medewete ontvang en dit in Bethlehem by H.W. van Raalte, 'n prokureur, gedeponeer. Hy kon egter nie verantwoordelikheid vir die 1000 pond sterling aanvaar nie "indien dit ... zonder ... toestemming door den vijand opgeeischt [sou] word [nie]" (VAB: CO 74 4309/01. HW van Raalte, kopie van waarborg, 26-7-1900).

Vir die laaste maal het Theunis en Tibbie mekaar op 14 Julie 1900 te midde van 'n kritieke oorlogsituasie in Fouriesburg gegroet. Al was Theunis deel van generaal De Wet se kommando, 'n voortvlugtende, en "without a republic, a man without a home, [he was] still full of pluck, cheerful and unbeaten" (Rompel, 1902:73). Die onttrekking van die Boeremagte uit Fouriesburg het saamgeval met die binnemarsjeer van die eerste Skotse soldate onder luitenantgeneraal A. Hunter, wat ironies genoeg, 'n afstammeling was van daardie selfde Pierre Fraser wat destyds uit Frankryk saam met die oorspronklike stamvaders na Skotland verhuis het (Beyers, 1977:309; Moncreiffe, 1967:145). Ten spyte van die veel geroemde "wonderful courtesy" waarmee die Britse pers gereeld na die hantering van die Boereleiers se eggenotes verwys het (Openbare Biblioteek Bloemfontein:ongeïdentifiseerde koerantknipsel, 17-7-1900), en die hoflikheid van die Britse bevelvoerder, het dit mettertyd tot haar deurgedring dat sy, in haar eie woorde, "the first woman in my position [was] that was taken prisoner" (VAB: A156 1/1/17. Review of Reviews, 19-9-1902).

Dit is Tibbie in Afrikanergeledere tot die dag van haar dood ten goede gereken dat sy volstrek geweier het om na Europa uit te wyk (Van der Merwe, 1921: 105), of om, soos die vrou van generaal Louis Botha, druk op Theunis uit te oefen om hom op generaal Hunter se versoek te probeer oortuig van die nutteloosheid daarvan om die oorlog voort te sit (Ineg: PV 181 4/1/2/2 "Gevangeneming").

Die oorlog het haar nou in sy felheid getref: sy was 'n krygsgevangene, reeds "wife of the ex-President", soos vermeld in die Kaapse en Britse koerante (The London Times, 28-7-1900; The Cape Argus, 30-7-1900; The Cape Times, 31-71900 ), 'n de facto Britse burger na die anneksasie van die Vrystaat op $24 \mathrm{Mei}$ 1900 (Bloemfontein Post, 28-5-1900), en sy moes haar onverwyld met 'n geleide by die militêre goewerneur in Bloemfontein aanmeld (VAB:A156 1/1/18. mev. Fraser-RIS. c. 1900; De Zuid-Afrikaan, 8-7-1900). Haar versoek om na die familieplaas, Onze Rust, te gaan, is geweier.

Niks is haar gespaar nie: sy was ooggetuie van die intense vernedering toe meer as 4000 verslane burgers ongewapend op pad na krygsgevangenekampe op Ceylon (Sri Lanka) te perd verbygery het nadat hulle op 28 Julie 1900 onder generaal Prinsloo net agtien kilometer suidoos van Fouriesburg oorgegee het 
(Amery, 1906:342; Maurice, 1908:305,306; The London Times, 10-8-1900; Van Rensburg, 1969:19). Sy is toegelaat om apart van die stofgehulde kommando's te reis onder geleide van luitenant-kolonel A.M. Brookfield, 'n lid van die Britse parlement en 'n hoflike heer uit die Ou Skool (Ineg: PV 181 2/8/1/1/4 vol. II. AM Brookfield-RIS, 28-7-1900; Ineg: PV 181 2/8/1/1/3 vol. I. RIS-MTS 24-51902).

\section{4. "The change ... in Bloemfontein ... was so great"}

"You can't think when I first returned to Bloemfontein how utterly forlorn \& homesick I felt, the change was so great", het Tibbie die verandering in haar en hul mense se posisie later aan Theunis beskryf (Ineg: PV 181 2/8/1/1/3. RISMTS, 25-5-1902). Sy was nie meer in die bevoorregte posisie om gunste aan ander te bewys nie en het die wapperende Union Jacks op al die regeringsgeboue in die hoofstad met onbeskryflike bitterheid gade geslaan (Ineg: PV 181 2/8/1/1/3 vol. I. RIS-MTS, 25-5-1902). Sy was uitgelewer aan die nukke en grille, passe en permitte van die Britse militêre burokrate: die willekeurige besluite oor haar huisvesting; byvoorbeeld die kleinlike beperkingsmaatreëls op haar vryheid; die verbod op kommunikasie met Theunis om so blootgestel te word aan elke wilde gerug oor die president se welstand en in die Engelse pers die voortdurende verdagmakery van Theunis se persoon. Emily Hobhouse, 'n Britse vrou werksaam in die konsentrasiekampe, het haar verbasing oor die onverskillige behandeling van Tibbie in korrespondensie vermeld: "As they no longer recognize Steyn as President one wonders why thus torment his wife" (VAB: A156 3/11. Ontwerp outobiografie, IV, EH(Bloemfontein)-lady Hobhouse, 26-1-1901). 'n Gewapende wag het haar geleide gedoen nadat sy om gesondheidredes toegelaat is om daaglikse rytogte met die spaaider te onderneem (Ineg: PV 181 2/8/1/1/3 vol. I. RIS-MTS, 30-5-1902, 24-5-1902; VAB: A156 1/1/18. mev. Fraser-RIS, 19-12-1902).

Hul lewensnoodsaaklike dokumente - dié wat sy nie inderhaas in Fouriesburg vernietig het nie - moes sy sonder meer aan die Britse militêre owerheid oorhandig (Ineg: PV 181 2/8/1/1/1. A. Browne namens militêre goewerneur, 308-1900). Sy was selfs onder verdenking dat sy gesteelde staatseiendom in haar besit gehad het en moes die houers wat sy voor die ontruiming van die Presidensie na die Stollreithers vervoer het, voor die amptenary oopmaak en bewys dat die silwer en linne daarbinne wel haar persoonlike eiendom was (Ineg: PV 181 4/1/2/2. "Gevangeneming").

Die vae skeidslyne tussen Brits- en Republikeinsgesindes in die vooroorlogse Bloemfontein het nou skeure van onversoenbaarheid geword. Behalwe vir die ou Republikeinse garde - haar skoonsuster, Hannie Blignaut, die Fichardts, Stollreithers, Fischers, Frauendorfers - is sy versaak deur die meeste pseudovriende wat, in die woorde van Dora Poultney, "have succumbed to khaki fever" (Ineg: PV 181 2/8/1/1/1. Dora Poultney(Durban)-RIS, 26-7-1901). Die 
ernstigste probleme waarmee Tibbie te kampe gehad het, het sy ironies genoeg ondervind "often \& mostly at the hands of our own people" (Ineg: PV 181 2/8/1/1/3 vol. I. RIS-MTS, 2-6-1902; VAB: A156 1/1/14. WJC Brebner-RIS, 16-1902). Uit 'n oord vanwaar sy dit die minste verwag het, naamlik van die Britse hoof van administrasie in die Oranjerivierkolonie, sir Hamilton GooldAdams, het sy egter menige, soos sy dit genoem het, "little acts of kindness" ontvang (Ineg: PV 181 2/8/1/1/2. RIS-MTS, 10-11-190I; VAB: A156 1/1/40. RIS-John Brown, 2-8-1901). Herbert Baker, die bekende argitek wat Bloemfontein in die oorlogsjare besoek het, het tewens melding gemaak van "[what] a pleasure ... it was ... to see his relationship with Mrs. Steyn, a woman of great dignity" (Baker, 1944:51). Goold-Adams was, soos Brookfield, van die Ou Skool en het haar op soveel maniere tegemoet gekom dat Dora, haar vriendin, haar later speels geterg het met "your old Beau the Luit. Governor" (VAB: A156 1/1/21. Dora Poultney-RIS, 23-7-1903).

Algaande het die status wat Tibbie as so vernederend ervaar het, gegroei en is sy deur die republikeinsgesindes sowel as die veroweraars beskou as 'n simbool van verset en volharding in hul midde. Tibbie se teenwoordigheid in Bloemfontein was vir die Britse bewindhebbers 'n steen des aanstoots: sy was immers die lewende verpersoonliking van die onoorwonne Boererepublieke ten spyte van die Britse anneksasies. Haar rol sou nie meer net dié van 'n voetnoot in geskiedskrywing wees nie: sy het alreeds haar geeërde plek in die geskiedenis verdien. In vergelyking met die eggenotes van ander prominente Boereleiers, "[who] were treated as show-pieces of imperial generosity", het die onverskillige behandeling wat Tibbie te beurt geval het, die beste in haar laat ontluik. Die besef dat sy "would have to fight [her] own battles $\&$ to overcome difficulties", soos sy dit uitgedruk het, het vir goed die afhanklike Tibbie agtergelaat (Openbare Biblioteek Bloemfontein: ongeïdentifiseerde koerantknipsel onder opskrif "Wonderful courtesy", 17-7-1900; Pakenham, 1979:450; Ineg: PV 181 2/8/1/1/2. RIS-MTS, 18-4-1902). Die loutering wat veroorsaak is deur die wegval van die vertroude stutte, die geborgenheid wat sy in haarself moes vind, haar verwysingsraamwerk van mense en omstandighede wat radikaal aan die verander was, het 'n suiwerder produk te voorskyn gebring wat bo omstandighede kon uitstyg. Dat sy in haar memoires meld dat "g'n Engelsman [moes] sien hoe ellendig dit haar laat voel het nie", getuig van haar bewuswording van 'n Afrikanerskap - onbegrens deur taal - wat wêrelde verwyder was van wat voorheen vaag en onbeduidend voorgekom het (VAB: A156 6/1. "Ouma dikteer").

Ten spyte daarvan dat die siviele lewe in Bloemfontein - "[was] hemmed and hedged in ... by military rules [it was] ... truly ... an imprisonment", volgens die oordeel van Emily Hobhouse - het Tibbie betreklik gemaklik vertoef in die huis in Zastronstraat wat vir haar deur die militêre owerheid bekom is - 'n huis wat destyds nog aan die buitewyke van die dorp was (VAB: A156 3/11. Ontwerp- 
outobiografie, IV. EH(Bloemfontein)-lady Hobhouse, 18-2-1901). Sy is aanvanklik toegelaat om groente en vrugte van Onze Rust te verkry totdat die voorreg later opgeskort is omdat die plaas benodig is as 'n voorradedepot vir perde.

Haar ontmoeting en ontluikende vriendskap met 'n Britse feminis - toe onafhanklike individualisme by 'n vrou nog 'n rariteit was - het vir haar vervulling gebied toe sy dit broodnodig gehad het. Dit was 'n geval van teenoorgesteldes wat gemeensaamheid gevind het in 'n saak buite hulself, die rede naamlik waarom Emily Hobhouse as eresekretaresse van die Vrou-enKinders-Noodlenigingsfonds na Suid-Afrika gekom het: die noodlydende Boerevroue en -kinders in die konsentrasiekampe. Terwyl hul agtergrond, eienaardig genoeg, heelwat ooreenkomste getoon het, het hul temperament egter hemelsbreed verskil: mejuffrou Hobhouse was 'n sterk individualis, 'n pasifis, welsprekend - iemand wat haarself meestal as 'n man se gelyke of meerdere beskou het - en met goeie reg. Tibbie, weer, was nog in daardie stadium die vertroetelde Victoriaanse middelklas-eggenote. Tog het 'n vriendskap ontluik tussen die twee Engelssprekende, middeljarige predikantsdogters wat eers beëindig is met die dood van mejuffrou Hobhouse 'n kwarteeu later.

\section{5. "A more terrible chapter of the war was opening"}

Inmiddels het die oorlog in felheid toegneem en, volgens Deneys Reitz, seun van 'n Vrystaatse oudpresident, F.W. Reitz, "a more terrible chapter of the war was opening" (Reitz, 1929:147). Die verskroeide-aardebeleid waarmee lord Kitchener, die Britse militêre bevelvoerder in Suid-Afrika, die strydende Boereguerillas van lewensmiddele wou ontneem, het genoodsaak dat duisende hawelose Boerevroue en -kinders byeengebring is in kampe wat eintlik maar konsentrasiepunte vir vlugtelinge naby 'n spoorweg was. Van haar hoërliggende huis in Zastronstraat kon Tibbie die Bloemfonteinse konsentrasiekamp ten weste van haar sien en meermale ruik ook as gevolg van die onhigiëniese toestande daar (Spies, 1977:269). Reeds teen Mei 1901 was die kamp onhanteerbaar groot. Die uitermate hoë sterftesyfer in hierdie kamp was 383 per duisend per jaar, veral onder kinders. Hierdie toestande was egter verteenwoordigend van sowat 45 ander konsentrasiekampe in die oorlogsgebied (Otto, 1954:74, 76; Kriel, 1957:44, 45).

Die verslegtende oorlogsituasie het Tibbie direk geraak, want op 26 Oktober 1900 is die 63-jarige ds. Fraser en Emeline vanaf Philippolis in 'n oop treintrok na Bloemfontein vervoer waar haar vader in die tronk aangehou is en haar jonger suster verplig is om die vyf kilometer na die Bloemfonteinse konsentrasiekamp te voet af te lê (VAB: A156 1/1/40. ds. Fraser-John Brown, 5-121900). Die besluit het geskied volgens die Britse militêre kriterium dat "all influential men not absolutely loyal to us were removed" (VAB: CO 26 1291/01. PM Kirkpatrick-provoos-maarskalk, 6-7-1901). Omdat haar oom John 
Fraser groot invloed by die Britse besettingsmag in die hoofstad gehad het, het Tibbie, ten spyte van die argwaan tussen hom en Theunis, by hom om hulp gaan aanklop. Ds. Fraser is op borg van 500 pond vrygelaat op sterkte van sy halforoer se "undertaking to stand bail for his future behaviour" (Fraser, 1922: 295; Bosch, 1962:50, 51) Die ingeperkte ds. Fraser en Emeline het by Tibbie gebly en is ook soos sy, nie toegelaat om humanitêre werk in Bloemfontein of die nabygeleë konsentrasiekampe te verrig nie (VAB: A156 1/1/40. ds. FraserJohn Brown, 5-12-1900).

Dit was 'n veranderde Tibbie wat luitenant-generaal Hunter, dieselfde offisier wat sy met haar gevangeneming in Fouriesburg ontmoet het, nou gekonfronteer het: daar was geen beduidenis meer van die vroeëre onsekere senuagtigheid of hartkloppings nie. Haar ferm, dog vriendelike aandrang op haar vader se terugstuur na sy tuisdorp het vrugte afgewerp en 'n permit is aan hom toegestaan om na Philippolis terug te keer (VAB: A156 1/1/40. RIS-John Brown, 14-2-1902). Omdat ds. Fraser op 'n later stadium geweier het om inligting aan 'n Britse kolonne onder kolonel Byng te verskaf, is hy beskou as "politically against us ... an old firebrand" (VAB: CO 50 2852/01. Henry(onduidelik)-Harry, 19-8-1901), en skaars agt maande later is hy weer gestuur na die Bethulie-konsentrasiekamp (VAB: CO 50 2865/01. W Gosling-adjunk-administrateur, 8-8-1901). Hierdie keer het haar broer, Harry wat polities in die Britse kamp was, tot Tibbie se redding gekom, en het sy invloedryke posisie by die East Rand Mines sowel as Goold-Adams se tussentrede in Bloemfontein dit moontlik gemaak dat die Frasergesin op 14 Augustus 1901 na Oos-Londen gestuur is (VAB: CO 50 2852/01. LM Salmon-HF Wilson, 14-8-1901; VAB: A156 1/1/40. RIS-John Brown, 30-9-1901; Ineg: PV 181 2/8/1/1/2. RIS-MTS, 10-11-1901). Philippolis is ontruim en die pastorie met al die waardevolle Fraserbesittings daarin, is afgebrand (VAB: A156 1/1/18. ds. Fraser(Oos-Londen)-RIS, 1-7-1902, mev. Fraser-RIS. 5-11-1901. VAB: A357. ds. Fraser-Margaret Gillet, 13-8-1910).

Al Tibbie se pogings om verligting in die Bloemfonteinse konsentrasiekamp te bring deur onder andere klaarvoorbereide voedsel daarheen te stuur, is deur die militêre owerheid verydel, omdat Kitchener slegs sulke toestemming verleen het aan diegene wat hy beskou het as polities meer neutraal (VAB: Al56 6/1. "Ouma dikteer"; Ineg: PV 181 4/1/2/2. "Myn verblyf in Bloemfontein"; Onze Rust: RIS- lady Farrer, 29-5-1901; VAB: 13/2. A Hume-M Fleck, 26-2-1901; VAB: A156 3/11. Ontwerp-outobiografie, IV. EH-L Hobhouse, 11-2-1901). Uiteindelik, is Tibbie in Desember 1901 toegelaat - waarskynlik as propagandamiddel - om slegs die hospitaal in die Bloemfonteinse kamp te besoek (VAB: Al56 6/l. "Ouma dikteer"). Maar dit het gebeur net toe die broodnodige verbeteringe waarop mejuffrou Hobhouse aangedring het, reeds geïmplementeer was. 
Alhoewel Tibbie in 'n brief aan lady Farrer, eresekretaresse van die Vrou-enKinders-Noodlenigingsfonds, meld dat sy beïndruk was met die verbeteringe in die hospitaalsituasie, was sy nogtans diep ontsteld (Ineg: PV 181 2/8/1/1/1. RISlady Farrer, 14-3-1902; VAB: Al56 1/1/40. RIS-John Brown, 4-4-1902). In 'n brief aan haar boesemvriendin in Duitsland, oorweeg sy - heeltemal irrasioneel en emosioneel - om as vrywillige ingesetene na die Bloemfontein-kamp te gaan. Dora Poultney se geskokte teenkanting spreek duidelik:

We feel quite horrified at the idea of such a thing \& hope there will be such serious opposition in your immediate circle, that you will be afraid to mention the subject again. None of us will ever be able to look Theunis in the face again if we did not make every effort to prevent such a thing ... but the camp - never! What would Theunis say? (Ineg: PV 181 2/8/1/1/2. Dora Poultney-RIS, 21-3-1902).

\section{6. "The six were selected as the worst of a number of irreconcilable women"}

Vanaf September 1901 het Kitchener die konfiskering van burgers se eiendom en die deportering van die leiers se eggenotes as ' $n$ verdere strafmaatreël aangewend om die vegtende Republikeine tot oorgawe te dwing. St. John Broderick, die Britse oorlogsekretaris, het die voorstel persoonlik gesteun maar was nogtans sensitief vir die Europese openbare mening, want "their deportation will raise a howl with a shade of justification as no legislation has been passed" (Spies, 1977:273). Kitchener moes hom vergewis dat die voordele wat hy met sy beoogde strafmaatreell probeer verkry het, swaarder sou weeg as die nadele. Humanitêre redes het egter nooit vir hom swaarder geweeg as militêre strategieë nie

In 'n vertroulike briefie lig Goold-Adams Tibbie op 22 Oktober 1901 in oor hierdie beoogde verbanning "to enable you to have more time to get ready" (Ineg: PV 181 2/8/1/1/1. H. Goold-Adams-RIS, 22-10-1901). Alhoewel dit weliswaar vir haar ' $n$ verligting sou gewees het om soos Annie Botha, eggenote van generaal Louis Botha, na Europa uit te wyk, was sy diep ontsteld want onder die omstandighede, skryf sy aan 'n familievriend, "I ... could [not] have felt happy to be so far removed from my husband while he was still fighting \& exposed to so many dangers" (VAB: A156 1/1/40. RIS-John Brown, 30-9-1901, 4-4-1902).

Sy het egter op grond van Goold-Adams se waarskuwing die nodige voorbereidings getref. Die Britse regering sou finansiële verantwoordelikheid vir Tibbie se onderhoud net tot in Europa aanvaar; daarna was sy op haarself aangewese (Ineg: PV 181 2/8/1/1/2. RIS-MTS, 10-11-1901; VAB: A156 1/1/39. RIS-lady Duncan, 6-7-1946). Die terugkry van haar fondse wat sy meer as 'n jaar tevore in Bethlehem gedeponeer het, het nou van kardinale belang geword (Ineg: PV 
181 2/8/1/1/2. RIS-HF Wilson, 23-12-1901). Sy verkoop haar besittings wat in dié omstandighede nutteloos geword het: van die meubels, die eenperdkar ("trap") sowel as die perde (VAB: A156 1/1/21. Harry-RIS, 4-12-1901; VAB: A156 1/1/30. RIS-MTS, 12-4-1902). Die silwerware, messegoed en skinkborde wat sy vir gebruik in die Presidensie aangekoop het, verkoop sy aan GooldAdams (VAB: A156 1/1/39. RIS-lady Duncan, 6-7-1946). Onverwags is sy egter weer eens gekonfronteer met die wete dat sy vir die Britse bewindhebbers persona non grata was: alle persoonlike bates van vooraanstaande Boercleiers is na die val van Bloemfontein deur die Britse regering bevries (Van Rensburg, 1967:154). Die 1000 pond, daardie bedrag wat onder meer Theunis se salaris ingesluit het en wat sy meer as 'n jaar tevore by die Bethlehemse prokureur inbetaal het, het hulle as hul eiendom beskou (Ineg: PV 181 2/8/1/1/2. HF Wilson-RIS, 11-12-1901) omdat hulle gemeen het dat 'n gedeelte van die som van 60000 pond afkomstig was van die Transvaalse regering (VAB: CO 74 4309/01. H Goold-Adams-H F Wilson, 19-12-1901).

Tibbie het haar saak persoonlik by Goold-Adams aanhangig gemaak (Kruger, 1949:37). In 'n brief het sy haar saak in detail uiteengesit: die feit dat sy 'n gedeelte van Theunis se salaris teen sy sin in ontvangs geneem het (Ineg: PV 181 2/8/1/1/2. HF Wilson-RIS, 23-12-1901; VAB: CO 74 4309/01. H GooldAdams-HF Wilson, 9-12-1901, Ineg: PV 181 2/8/1/1/5. RIS(Clarens)-WJ Leyds, 25-4-1902); ook dat sy haar bona fides as 't ware weer bo enige twyfel moes staaf met bewyse - 'n feitlik onbegonne taak in die lig van die dokumente wat sy vernietig het. Dat Goold-Adams haar saak weer eens persoonlik bevorder het, het uiteindelik, toe omstandighede in 1902 reeds verander het, die gewenste uitwerking gehad. Meer as 'n halfjaar nadat haar persoonlike finansies ter sprake gekom het, het die Britse regering 990 van die 1000 pond as 'n daad van eer aan haar terugbetaal (Ineg: PV 181 2/8/1/1/2. A Browne-RIS, 20-3-1902). (Die 10 pond is deur die prokureur as rente opgeêis (VAB: CO 74 4309/01. AM Marendish-sekr. van ORK, 18-12-1901).)

Intussen het die Britse minister van kolonies, J. Chamberlain, van Broderick stawende getuienis van die ondermynende bedrywighede van die eggenotes van die Boereleiers verlang wat hy kon publiseer voordat enigiets geimplementeer kon word. Volgens Kitchener "the six were selected" - Tibbie, mevrou Roux (moontlik die eggenote van generaal P.H. Roux), die eggenotes van Christaan de Wet, Schalk Burger, J.B.M. Hertzog, Tobias Smuts - "as the worst of a number of irreconcilable women" (Spies, 1977:274, 275). Kitchener, 'n militêre strateeg, wat gewoonlik sy doelwitte ten alle koste probeer deurforseer het, was ongeduldig dat die verlangde getuienis ontbreek het. Hulle was prominente Boerevrouens en dit was vir hom voldoende bewys: "[these women] do more harm here and I think Kruger should keep them, as he promised the burghers he would do" (Spies, 1977:173, 174). 
Tibbie en haar kinders is toegelaat om elk 'n brief aan Theunis te skryf, mits dit slegs persoonlike besonderhede sou bevat. Op die aand van 10 November 1901 het Tibbie haar lot afgewag, klaar gestewel en gespoor vir die volgende dag se reis en verskeping van Durban af met die SS Kronprinz. In 'n maratonbrief van sestien bladsye lank het sy haar hart - gedagtig aan 'n alomteenwoordige sensor - aan Theunis uitgestort. Niks sou vir haar te swaar wees om te dra nie, solank Theunis, die persoon waarom haar hele bestaan gewentel het, se lewe net gespaar bly:

How very painful it is to say 'Goodbye' to you, ... It is a wrench leaving South Africa \& you still fighting for your country \& your cause, ... My heart is full - words are after all poor exponents of the heart ... God bless \& keep you ... Yours forever (Ineg: PV 181 2/8/1/1/2. RIS-MTS, 10-11-1901, Gladys-MTS, 30-10-1901, Hannah-MTS, 19-11-1901; SA Biblioteek Kaapstad: MSC 33/3.2. Colin Steyn-MTS, 3-11-1901; PV 181 4/1/2/2 "Myn stuur naar Europa").

Tibbie en haar kinders se trauma en moeite van die vorige drie weke het nie te swaar op die Britse regering se gewete gerus nie. Kitchener kon nog steeds nie te voorskyn kom met die duidelike en eksplisiete getuienis oor die beweerde misdrywe wat Broderick verlang het nie. Op 11 November is haar vertrek tydelik uitgestel en vir nog agt dae het sy op hete kole gesit totdat die Britse kabinet uiteindelik op 19 November 1901 die voorstel eenparig afgekeur het (Spies, 1977:275). Dora Poultney se verontwaardiging oor die behandeling wat Tibbie te beurt geval het, was getemper deur die teenwoordigheid van die Britse sensor: "I think tho' you understand what this hot brain of mine thinks of the whole performance" (Ineg: PV 181 2/8/1/1/2. Dora Poultney(Berlyn)-RIS, 7-121901).

\section{7. "Words can never describe the feeling when I found my husband such a wreck"}

Die tekens van dubbelvisie wat Theunis op 18 Februarie 1902 vir die eerste keer ondervind het (Ineg: PV 181 2/8/1/1/17. MTS-ds. Fraser, 3-2-1904), was die eerste aanduiding dat die eik waarmee Theunis vergelyk is, inderdaad besig was om te kraak. Twee weke later het hy las van slap ooglede ondervind en teen 13 Mei 1902 het Theunis alle beheer oor sy ledemate verloor. Die spanning wat geskep is deur die vredesonderhandelings, tesame met bedorwe voedsel wat hy geëet het, het hom die finale knak toegedien (Fichardt, 1973:22, 49; Van der Merwe, 1921:36; VAB: A156 1/1/17 ongeïdentifiseerde Nederlandse koerant). Ten spyte van sy ernstige siekte was Theunis die spil waarom die vredesondehandelinge in Vereeniging, waar 60 volksverteenwoordigers vanaf 16 Mei 1902 bymekaar gekom het, gedraai het. Die skrif was egter reeds aan die muur en sy verswakte liggaamskragte laat hom toe om slegs twee vergaderings by te woon. Op 29 Mei 1902 bedank hy as staatspresident en vertrek na Krugersdorp vir 
geneeskundige hulp aan huis van dr. W.J. van der Merwe (VAB: Al56 1/1/31. JWC Brebner-RIS, 16-5-1902). Voor middernag 31 Mei 1902 het die formele ondertekening van die Vrede van Vereeniging in Melrosehuis in Pretoria plaasgevind.

Met die gevoel van oorwinning in die lug het die Britse owerheid die beperkinge op Tibbie verminder (Ineg: PV 181 2/8/1/1/2. RIS-MTS, 18-4-1902; Ineg: PV $1812 / 8 / 1 / 1 / 3$ vol. I. RIS-MTS, 5-6-1902). Onwetend het sy egter die grootste krisisuur in haar lewe genader. Op $30 \mathrm{Mei} 1902$ was sy vol ekstatiese verwagting om Theunis weer te sien - miskien 'n effe krank Theunis met hoogstens 'n oorkombare oogprobleem. In werklikheid het hy egter al die laaste drie weke lank vir sy lewe geveg. Sy is doelbewus in die duister gelaat oor die erns en omvang van sy siekte, hoofsaaklik omdat sy self siek was aan maagkoors en bronchitis (VAB: A156 6/1. "Herenig met President 1902"; Ineg: PV 181 2/8/1/1/1. RIS-MTS, 19-5-1902). Daarby skyn dit of Tibbie doelbewus geglo het dat die onwrikbare Theunis nie die slagoffer van enige siekte kon word nie (Ineg: PV 181 2/8/1/1/3 vol. I. RIS-MTS, 21-5-1902, 28-5-1902; Ineg: PV 181 2/8/1/1/5. RIS(Clarens)-madame Asinelli, 28-3-1903). Toe sy hom dus tien dae later in Krugersdorp sien, van sy nek af heeltemal verlam, sy stembande aangetas terwyl hy alles dubbel sien, was sy totaal verbysterd (VAB: A156 1/1/40. RIS(Scheveningen)-John Brown, 24-8-1902). Byna 'n jaar daarna het Tibbie nog die skok van hierdie ontmoeting herroep: "Words can never describe my feelings when I found my husband such a wreck" (Ineg: PV 181 2/8/1/1/5. RIS-madame Asinelli, 28-3-1903).

\section{Voleinding}

Die "delicate dependent wife [Theunis] left behind" (Ineg: PV 181 2/8/1/1/2. RIS-MTS, 26-5-1902, 18-4-1902), het geestelik en emosioneel volwasse geword, onafhanklik en weerbaar. En nou, te midde van soveel oënskynlik onoorkomelike probleme, het sy daardie innerlike krag geopenbaar waaroor 'n mens dikwels onwetend beskik en wat net te voorskyn kom, soos generaal Smuts dit gestel het, "in pain and anguish and sorrow, and once it appears, everything shrinks into insignificance before it". Dit is op 'n beslissende moment in die geskiedenis dat 'n vrou met hierdie eienskappe op die toneel verskyn, "and in her weakness turns the flowing tide of events" (Fry, 1929:292). Daardie vrou was Tibbie.

Die vloedgolf van algemene aanvaarding dat "Mr. Steyn's condition is [in any case] hopeless" (Schoeman, 1982:62), het sy gestuit deur daadwerklike optrede. In die getygolf van wanhoop het Tibbie teen welmenende advies in besluit om geneeskundige hulp vir Theunis in Europa te gaan soek (Ineg: PV 181 2/8/1/1/3. vol. I. RIS-lord Kitchener, 18-6-1902). En, teen alle verwagting in, oorleef Theunis tog die seereis na Europa en hier, te midde van uitstekende doktersbehandeling, die verandering van omgewing, die aanvaarding van die verlore 
onafhanklikheid as ' $\mathrm{n}$ voldonge feit sowel as die liefdevolle onderskraging van Tibbie, het Theunis, die neergevalle eik, die eerste tekens van herstel getoon.

Die groepie ontwortelde Afrikaners wat die Steyns vergesel het, het 'n gelukkige verposing in Europa se kuurstede gevind met Tibbie as die spil waarom die huishouding, emosionele peil en besluite oor geldsake gedraai het. "Zij was ... mij alles in alles, het Theunis aan sy skoonvader geskryf (VAB: Al56 1/1/30. MTS-ds. Fraser, 2-10-1904).

Terug in Suid-Afrika in 1905 het die Engelse pers na president Steyn as "a broken man" verwys (Barlow, 1952:110). Vir sy volksgenote was hy egter ten spyte van sy voortgesette liggaamlike swakheid "de ongekroonde koning van Zuid-Afrika ... Een koningzetel nam hij werklik in in het hart van het Afrikaner volk" (VAB: A156 3/3). Ook Tibbie het haar plek ingeneem in die hart van die volk wat sy ten slotte volledig haar eie gemaak het. Hierdie oorlog "rubbed out every distinction", in die woorde van Ben Bouwer, "but that of intrinsic quality", en sowel Tibbie as president Steyn "endured to the end without hope or reward, purely for the sake of an ideal. [It was] such select company" (Pretorius, 1991:281).

\section{Literatuurlys}

Amery, L.S. (ed) 1906. The Times history of the War in South Africa 1899-1902. IV. London : Samson Low, Marston

Barlow, A G. 1952. Almost in confidence. Cape Town: Country Life

Bosch, JA. 1962. Eeufeesgedenkboek van die NG gemeente Philippolis 1862-1962. Bloemfontein : Waarskynlik NG Sendingpers. (Onvermeld.)

Baker, H. 1944. Architecture and personalities. London : Country life.

Beyers, C.J. 1977. Suid-Afrikaanse Biografiese Woordeboek. III. Pretoria : Tafelberg.

Bigelow, P. 1898. White mans's Africa. New York : Harper \& Brothers.

Bradlow, E 1988. Children and childhood at the Cape in the 19th century. Kleio: 20.

Fichardt, T. 1973. The illness of President M.T. Steyn. Suid-Afrikaanse Mediese Tydskrif, November, 24.

Fraser, J.G 1922 Episodes in my life. Cape Town : Juta

Fry, A.P. 1929 Emily Hobhouse, a memoir compiled. London : Jonathan Cape.

Haasbroek, J 1977. Die rol van die Engelse gemeenskap in die Oranje-Vrystaat 1848-1859. Bloemfontein : UVS. (M.A.-verhandeling.)

Izedinova, S. 1977. A few months with the Boers, the war reminiscences of a Russian nursing sister. (Translated \& edited by Moody, C) Johannesburg : Perskor

Kriel, J D 1957. Emily Hobhouse en die nawee van die Anglo-Boereoorlog: 'n studie van altruisme en pasifisme Bloemfontein. UVS. (D Phil -proefskrif)

Kruger, N. 1949 Rachel lsabella Steyn, presidentsvrou. Kaapstad : Nasionale Pers.

Malan, J H. 1929. Die opkoms van 'n republiek of die geskiedenis van die OVS tot die jaar 1863 Bloemfontein : Nasionale Pers.

Maurice, H.G \& Grant, M.H. 1908. History of the War in South Africa, 1899-1902. (Compiled by the direction of His Majesty's Government.) III. London : Hurst \& Blackett.

Moncreiffe, I \& Hicks, D 1967. The Highland clans, the dynastic origins, chiefs and background of the clans connected with Highland history and some other families. London Barry \& Jenkins 
Otto, J C. 1954 Die konsentrasiekampe. Kaapstad : Nasionale Boekhandel.

Pakenham, T 1979. The Boer War. London : Jonathan Ball.

Poultney, D.O. 1936. Dawn to dusk London : Cassel.

Pretorius, F. 1991. Kommandolewe tydens die Anglo-Boereoorlog 1899-1902. Kaapstad Human \& Rousseau.

Reitz, D. 1929. Commando: A Boer journal of the Boer War. London : Faber \& Faber.

Rompel, F 1902 Marthinus Theunis Steijn Amsterdam : L.J Veen

Schoeman, K. 1980. Bloemfontein: die ontstaan van die stad 1846-1946. Kaapstad: Human \& Rousseau.

Schoeman, K. 1982. In liefde en trou, die lewe van pres. en mev. M.T. Steyn. Kaapstad : Human \& Rousseau

Schoeman, K. (ed.) 1985. Pen pictures of the past Vrijstatia, 5 Cape Town : Human \& Rousseau.

Scholtz, L 1999. Anglo-Boereoorlog was misdaad teen mensdom Sake van die dag Die Volksblad, Januarie, 8.

Spies, S. B. 1977. Methods of barbarism, Roberts and Kitchener and civilians in the Boer republics Jamuary 1900-May 1902. Cape Town: Human \& Rousseau.

Truter, E J.J. 1989 Rachel Isabella Steyn in die Oranje-Vrystaat 1865-1905. Pretoria UNISA. (M.A.-verhandeling.)

Truter, E J J. 1997. Tibbie: Haar lewe was haar boodskap. Kaapstad : Human \& Rousseau.

Van der Merwe, N.J. 1921. Marthinus Theunis Steyn, 'n lewensbeskrywing, II Kaapstad Nasionale Pers

Van Rensburg, A.P.J. 1967 Die ekonomiese herstel van die Afrikaner in die Oranjerivierkolonie 1902-1907. Argiefjaarboek vir Suid-Afrikaanse Geskiedenis, 1I. Johannesburg Staatsdrukker. (D.Phil-proefskrif.)

Van Rensburg, A P J 1969. Die skandkol wat nie wou toegroei nie. Die Huisgenoot, Augustus, 8 .

\section{Argivale bronne}

Die volgende afkortings geld in die voetnote: Rachel Isabella Steyn: RIS; Marthinus Theunis Steyn MTS; Emily Hobhouse: EH; Jan Christiaan Smuts: JCS

Vrystaatse Argiefbewaarplek (VAB): Bloemfontein

Colonial Secretary CO

CO 26 1291/01: Dutch Reformed Church and affairs in South Africa

CO 50 2852/01: Rev Fraser of Philippolis: enquiry by his son as to his whereabouts, of his mother and sister

CO 74 4309/01: Deposit of 1000 pounds with Mr. Van Raalte of Bethlehem by Mrs. Steyn: Proposed payment into Government account

\section{Aanwinste:}

A 13 Fleckversameling

A $13 / 2$

A156 Steynversameling

A156 3/3 plakboek met oorsese koerante omtrent pres Steyn se dood

A156 3/11 Emily Hobhouse: Ontwerp outobiografie, IV

Al56 6/1 Ouma dikteer; Herenig met President, 1902

Al56 1/1/14: briewe aan R I Steyn, ongedateerd, 1899-1923

A156 1/1/17: briewe aan familie en vriende

Al56 1/1/18: briewe aan pres. en mev. Steyn van familie en ouers, 1885-1930

Al56 1/1/21: briewe aan pres en mev. Steyn van broers en susters, 1883-1902

Al56 1/1/30: briewe aan pres. en mev. Steyn van diverse persone, 1884-1952 (1905) 
A156 1/1/31: briewe aan pres. en mev. Steyn van diverse persone, 1884-1905

A156 1/1/39: diverse korrespondensie, 1856-1938 (1905)

A156 1/1/40: diverse korrespondensie, 156-1938 (1905)

A357 Mev. C. Smuts-Clarkversameling

Instituut vir Eietydse Geskiedenis (Ineg) UVS: Bloemfontein (tans Argief vir Eietydse Aangeleenthede (AEA))

PV 181: Senator I.G. Visserversameling

PV 181 2/7/1/1/6: korrespondensie, 1884-1902

PV 181 2/7/1/1/1: korrespondensie, 1884-1902

PV 181 2/8/1/1/1: korrespondensie, 1884-1902

PV 181 2/8/1/1/2: korrespondensie, 1884-1902

PV 181 2/8/1/1/3 vol. I, II: korrespondensie, 1884-1902

PV 181 2/8/1/1/4: korrespondensie, 1902-1911

PV 181 2/8/1/1/5: korrespondensie, 1902-1911

PV 181 2/8/1/1/7: korrespondensie, 1902-1911

PV 181 4/1/2/2: Gevangeneming; Myn verblyf in Bloemfontein; Myn stuur naar Europa PV 181 4/8/1/1/3 vol. I: artikels, geskrifte

Suid-Afrikaanse Biblioteek: Kaapstad

MSC 33/3. 1-3.7 R.M Steynversameling, korrespondensie van Colin Steyn

Transvaalse Argiefbewaarplek (TAB): Pretoria

SSA 728 RA 1274/98, 1618/98 Inkomende stukke

Vrystaatse Kerkargief van die NGK (VKA): Bloemfontein

Doopregister (1890-1911)

Onze Rust: Bloemfontein

Brief RIS-lady Farrer 29-5-1901

Openbare Biblioteek: Bloemfontein

Leviseur, Elsa. Diary October 1899-March 1900

Periodieke publikasies:

Bloemfontein Post 28-5-1900

De Express 1896, 1898, 1899, 1900

The Friend 1898

Cape Argus Weekly 17-2-1898

Cape Argus Weekly 28-9-1898

De Zuid-Afrikaan 17-3-1900, 8-7-1900

Review of Reviews 19-9-1902 (VAB A156 1/1/17)

The London Times January-September 1900

The Cape Argus 30-7-1900

The Cape Times 31-7-1900 
Rachel Isabella Steyn by haar man, pres. M.T. Steyn

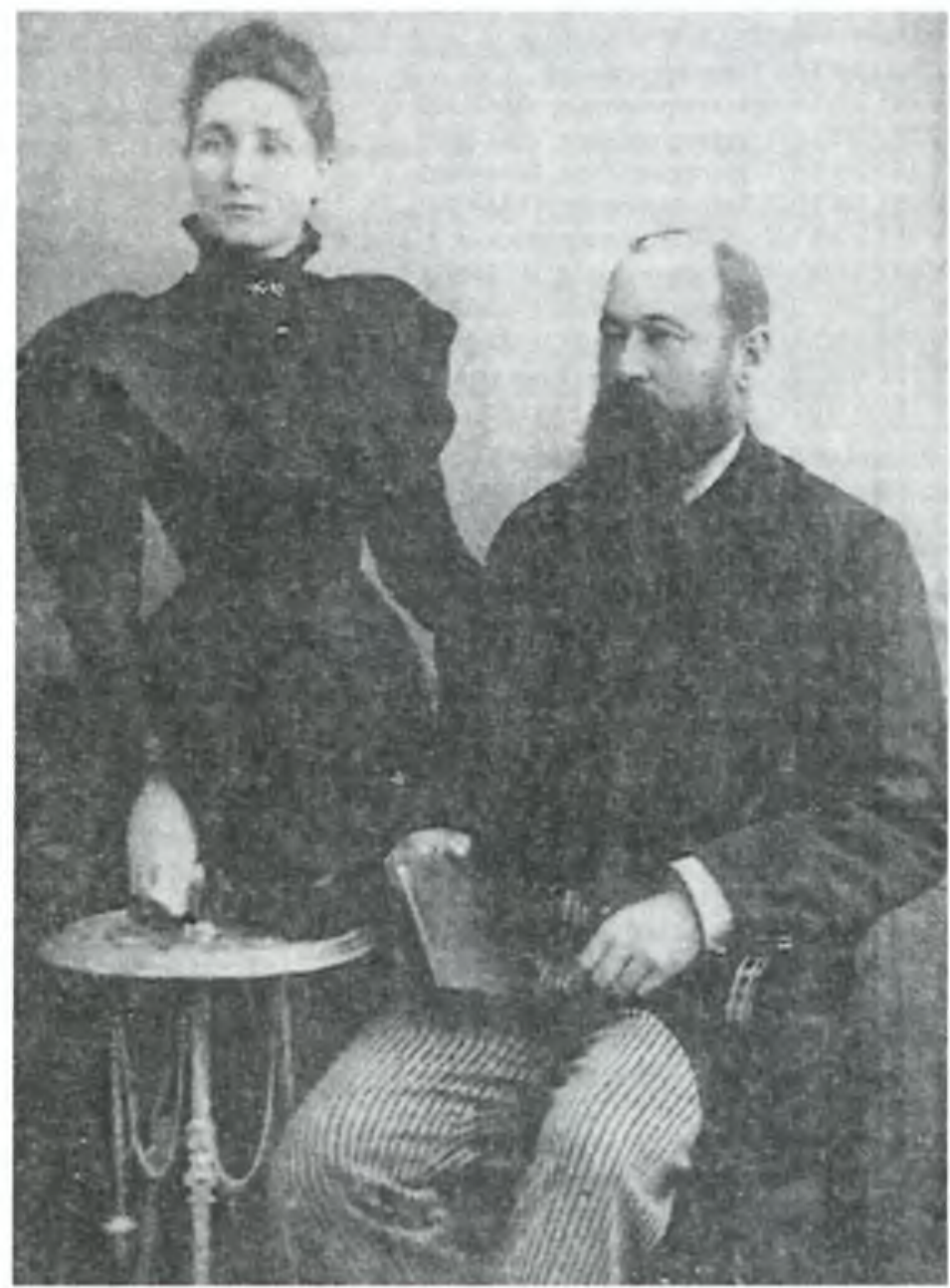

Fotomateriaal oorgeneem uit omslagfoto van Truter, Elbie. 1997. Tibbie. Rachel Isabella Steyn. Haar lewe was haar boodskap. Kaapstad : Human \& Rousseau. 